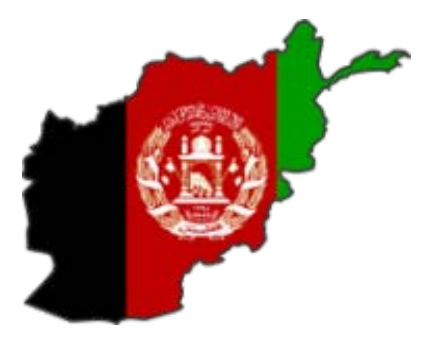

Independent Joint Anti-Corruption Monitoring and Evaluation Committee

\title{
VCA Report on \\ University Internal Examination Process
}

(translated from Dari)

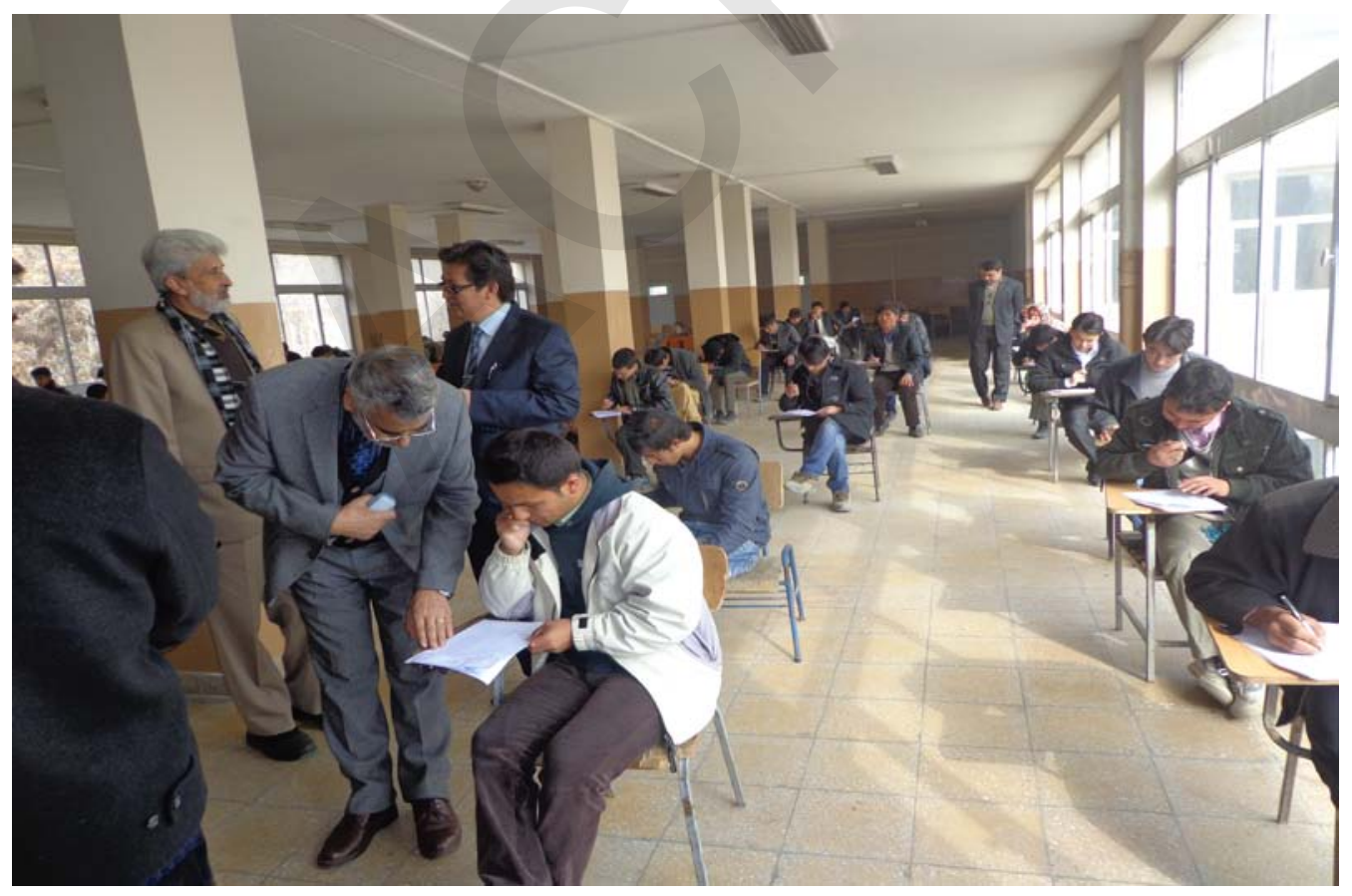

Kabul

October 2013 
BA

Bachelor of Arts

\section{HRD Cluster}

Human Resources Development Cluster

KU

Kabul University

KMU

Kabul Medical University

KPU

Kabul Polytechnic University

KEU

Kabul Educational University

MEC

Independent Joint Anti-corruption Monitoring and Evaluation Committee

MoHE

Ministry of Higher Education

NPP

National Priority Program

MSI

Management Systems International

P\&G

Pay and Grading

USAID

United States Agency for International Development

VCA

Vulnerability to Corruption Assessment 


\section{Contents}

Acronyms 2

Contents 3

VCA Objective 5

Introduction to MEC $\quad 6$

i. The Committee 6

ii. MEC Secretariat 6

iii. The VCA Unit 6

I. Report Summary 7

i. Context 7

ii. Findings 8

iii. Vulnerabilities to corruption $\quad 8$

iv. Recommendations to address vulnerabilities 8

II. Preface 9

i. Situational analysis of the exam process 9

ii. The need for a VCA 10

iii. Entities involved in the internal exam process 10

iv. Areas covered by the VCA 10

v. VCA methodology 10

III. Assessment of legal framework and legislative documents of 12 the process

i. Interviewees' perspective of the legal framework 12

ii. The existence of legislative documents 13

iii. Sufficiency of the legal framework 13

iv. Bill for the BA credit system in higher education institutions 13

v. Exams bill for higher education institutions 14

vi. Decisions of the meeting between MOHE and student $\quad 14$ representatives

vii. Personal decisions in the process 14

viii. Execution of the legal framework 15

ix. Enforcement of the legal framework 17

x. Vulnerabilities related to the legal framework 17

xi. Recommendations 17 
IV. Organizational Structure and Human Resources Related to the 18 Internal Exam Process

i. Interviewees' perspective of the human resources structure 19

ii. Sufficiency of human resources 19

iii. Knowledge and experience of staff 19

iv. Presence of terms of reference for staff 20

v. Professionalism of staff 20

vi. Staff engagement 20

vii. Sincerity of staff 20

viii. Abuse of final semester exams 20

ix. Vulnerabilities related to human resources 21

x. Recommendations 21

V. De Facto Practices in the Internal Exams Process 22

i. Stages in the internal exams process 22

ii. Interviewees' comments 23

iii. Personal activities of staff 23

iv. Management and control of staff performance 23

v. Unofficial recognition of rights, duties and responsibilities 24

vi. Undue influence and improper direction 24

vii. Gifts 24

viii. Awareness of corruption, misconduct and unprofessional 24 behavior

ix. Job security

x. Conflicts of interest

xi. Non-compliance and variance of procedures 25

xii. Satisfaction with the Complaint Investigation Committee 25

xiii. Provision of exam papers and answer-key 26

xiv. Vulnerabilities to corruption 26

$x v$.Recommendations 26

VI. Information Management in the Internal Exam Process 27

$\begin{array}{ll}\text { i. Current practices } & 28\end{array}$

ii. The existence of a system for information management 28

iii. Time intensiveness of the system 28

iv. Information security 28

v. Potential for misuse of the information management system 29

vi. Vulnerabilities to corruption 29

vii. Recommendations 29

$\begin{array}{ll}\text { Sources } & 30\end{array}$

$\begin{array}{ll}\text { Annex } & 31\end{array}$ 


\section{The VCA objective}

The purpose of conducting a VCA on the process of university exams is to identify forms, sources, implications, extent of corruption and vulnerabilities to administrative corruption; present appropriate recommendations in order to improve and speed up the working process; and to protect the process from potential vulnerabilities to administrative corruption. 


\section{Introduction to MEC}

\section{i. The Committee}

As suggested by its name, MEC is an independent joint Afghan/international committee. The Committee was established based on the Presidential Decree 61 (March 18, 2010) after the need to monitor efforts to fight corruption was identified. The Committee is composed of six reputable experts, three of whom are Afghan and three who are international. National members of the Committee are appointed by the President of Afghanistan and the three international members are proposed by the international community.

The purpose behind the establishment of MEC is to oversee the Afghan government and international community's performance in the fight against corruption independently and in a precise manner. Additionally, the Committee is responsible for developing recommendations and benchmarks directed to national and international institutions and to monitor their implementation. The Committee prepares reports on the progress of the benchmarks and its activities every six months and presents it to the President, the National Assembly, the Afghan public and international community. Likewise, the independence of MEC has been recognized as an irrefutable principle by the Afghan government and international community that has provided the Committee with power to conduct its work effectively.

\section{ii. MEC Secretariat}

MEC is supported by a technical secretariat comprised of national and international staff. The Secretariat is led by an Executive Director and is divided into three main pillars (Governance, Prevention, and Law Enforcement) consisting of an international expert, a national advisor, and a national officer, with over-arching policy expertise provided by a Senior Policy Advisor. The Secretariat works closely with the parties implicated by the recommendations and benchmarks to ensure that they are implemented. The Secretariat also consists of a VCA Unit responsible for undertaking the VCAs.

\section{iii. The VCA Unit}

Part of MEC's mandate is to provide recommendations to institutions to improve their working procedures and processes in providing public services. This objective requires precise identification of vulnerabilities to public services and other agencies' functioning procedures. In 2012, MEC, in partnership with MSI, established a VCA Unit within the MEC Secretariat to conduct VCAs covering a variety of public service areas.

VCAs are a mechanism used to identify susceptibilities to corruption in government processes and develop strategies to reduce the vulnerabilities. The VCA Unit began operations in September 2012. 


\section{Report Summary}

\section{i. Context}

Afghanistan, as a country decimated by three decades of war, is unfortunately populated by a large number of illiterate people. After the collapse of the Taliban in 2001 and the selection of the interim government, the improvement of Afghanistan's universities and higher education institutions became a focus of the government's leadership. However, the capacity limits of the young government meant that it was not able to meet the needs of the majority of university applicants. Nevertheless, MoHE, despite all the challenges it faced, managed to provide education for over 150,000 students locally and abroad. The growing number of students in universities speaks volumes for the government and particularly the Ministry's achievements; nevertheless, higher education continues to face challenges and is exposed to corruption. It is in this light that certain challenges emerged during the universities' internal exams and entry tests, which in some cases have seen incidents of corruption.

The issue of the universities' internal exams is of major importance and plays a role in improving the teaching quality as well as paving the way for fair student admissions. MoHE plays a role by compiling laws, regulations, policies, procedures and bills to cover a variety of services and circulates these to universities and other higher educational institutions for implementation. Furthermore, the Ministry monitors the implementation of enrollment procedures at universities and higher education institutions. The Ministry also establishes coordination between the higher education institutes and national and international entities.

The VCA Unit of MEC carried out an assessment on the following areas of universities' examination process: legal and administrative framework; structure and human resources; de facto activities and the information management system. Since the aim of the VCA Unit is to identify and assess points vulnerable to corruption, the team availed itself of multiple research methods.

\section{ii. Findings}

The VCA Unit, in cooperation with the responsible directorates, has tried to collect and analyze all legal and administrative documents related to the internal exam process. Legal documents given to the VCA Unit by MoHE were related to the credit system of Afghan higher education institutions for obtaining a BA, as well as the terms for the exams of higher education institutions. Furthermore, organizational structure documents and terms of reference for professors and other staff engaged in this process were also gathered. Due to the confidentiality of exam papers, however, the exam questions could not be included in the analysis. Therefore the details of internal exams were determined through interviews with the professors and staff engaged in the process.

The questionnaire clearly showed the vulnerable points to corruption in the exam process. Although teachers and staff do not see themselves as a separate working entity, they conceded that the process is vulnerable to corruption. Substandard methods of teaching, weaknesses of the legal framework, disobedient teachers, interference of Members of Parliament and influential figures of government in universities' affairs (particularly internal exams); political, racial and tribal prejudices, abuses of power by some teachers, and weak and irregular monitoring are all vulnerabilities to corruption inherent in the exams process. 


\section{iii. Vulnerabilities to corruption}

After a series of studies and analyzing the available information, the VCA Unit concluded that there are just three relevant documents pertaining to the exam process: the terms for higher education institution exams, terms for giving credit for higher education institutes, and procedures for final exams at the end of each semester. The documents have problems such as being vague, contradictory, repetitive and possessing inapplicable clauses, and subsequently need correction. However, the biggest challenges lie in the execution of the provisions included in the documents. Most terms and procedures are not implemented and are not followed by the professors.

As well as the legal framework, the VCA Unit looked into the organizational structure, human resources, de facto practices, and information management in the process in order to determine the vulnerabilities to corruption. The VCA Unit held group interviews and roundtable discussions with the participation of professors, students and staff of different levels to obtain information. In general, information obtained from different sources indicates:

- Teachers in universities are unfamiliar with the credit system;

- Limited professionalism in all universities, particularly in terms of adopting new methods of teaching;

- Disregard of the legal framework/rules for the exam process despite the existence of three legal documents (terms and procedures);

- Engagement of teachers in administration;

- External intervention and undue influences;

- Substandard compliance committees to consider student's compliance within the universities;

- Tribal, national, linguistic and religious prejudices in the course of internal exams of universities;

- The method of filing and the information management system give rise to the potential risk of documents disappearing - such as students' records - and at the same time provide an opportunity for fraud within responsible departments; and

- Access to information and documents is limited and it takes weeks to receive a document from the archive.

\section{iv. Recommendations to address vulnerabilities}

The recommendations presented in this report consider the vulnerabilities identified in the four mentioned areas of the assessment and are focused on:

- Developing policies, procedures, and regulations for the higher educational institutions, particularly regarding the internal exams of the universities;

- Assessing teachers and staff to meet the needs of students;

- Designing and implementing educational schemes to enhance capacity building of the teachers and staff;

- Developing the monitoring mechanism in the university's internal exams stage

- Simplifying and rationalizing the exam procedures; 
- Reforming the current system of archives, guaranteeing safety and confidentiality of documents and information;

- Computerizing the filing and information management system of the process; and

- Most importantly, designing a policy to avoid external interference in the exams process.

\section{Preface}

Three decades of war did not just destroy the infrastructure of the country and cause the death of a large number of people, but also destroyed the cultural and scientific foundations of the country which were once of great importance to the region. Intellectuals and experienced professors were forced to flee to the neighboring countries and other parts of the world, where they were forced to work in low-end jobs in order to provide for their families. This and unfair interferences of past regimes attributed to the disorder of educational institutions in the country. Afghanistan is now branded as a country populated by the largest number of illiterate people and the government is subsequently facing a lack of professionals with which to rebuild the country.

The collapse of the Taliban regime, the presence of international forces, and the establishment of the interim government after 2001 left many feeling optimistic that the country was once again heading towards development. Some scholars returned to the country after receiving higher education from institutions in other countries, and gave priority to the reorganization of academics in Afghanistan. Recent policies of the government's leadership with the intention of supporting and reorganizing academic entities also contributed to the development of such institutions.

Despite these efforts to develop higher education, the sector, like other parts of the government, has not been safe from the dangers of corruption and has slowly been infiltrated by corrupt practices as well.

\section{i. Situational analysis of the exam processes}

MoHE, like other institutions of the Islamic Republic of Afghanistan, faces many important challenges such as a lack of capacity and tools to deal with students' problems and respond to the demand of applicants for higher education. The internal exams of universities have become another challenge for MoHE. Besides the unprecedented number of students in the country, the Ministry has had to deal with instances of fraud, stealing, copying and other unfair practices during exams. The situation is exacerbated by the negligence of teachers and other staff involved in the examination process, thereby further increasing the vulnerability of the internal examination process to corruption.

The expansion of corruption has also been facilitated by the prevailing security situation in the country, the lack of rule of law and the execution of retribution and punishment; the limited numbers of experienced teachers, the unfulfilled need for standardized administration, as well as irrational interferences and other challenges. 


\section{ii. The need for a VCA}

The process of internal exams at universities not only represent internal struggles with corruption, but also casts a shadow over the activities of the government to improve institutes of education in terms of limiting the opportunities for profit seeking by corrupt people and opportunists. This has prompted students to raise their voices against being abused by some teachers and staff and made them assertively demand that their rights are respected. A certain number of students are not able to obtain the marks necessary for being admitted to university due to tribalism, political links, regionalism, discrimination of opinion, unfair personal profit seeking; sexual harassment of female students; bribery, and uneven influences. MoHE, as the entity responsible for responding to the matter, has issued two bills for exams, consisting of two systems of credit, in order to organize the process and prevent potential infiltration of corruption and other challenges, but in some cases negligence or weak monitoring of the implementation has meant that attempts at averting corruption and other challenges have not been very efficient.

Hence MEC arrived at a decision to carry out a comprehensive assessment to identify the vulnerabilities of the process to corruption and present technical and professional recommendations to MoHE to improve the situation.

\section{iii. Entities involved in the internal exams process}

MoHE, KU, PU, KMU, and KEU of Professor Rabani and Kardan University are to be directly assessed in terms of vulnerabilities to corruption in the exams stage.

\section{iv. Areas covered by the VCA}

The VCA Unit, after a primary consultation with the ministries and other relevant authorities, involved various officials and the coordination body for the implementation of the exams process to outline a plan for the assessment of vulnerabilities of the exams process to corruption. The plan consists of four areas of research:

- Legal and administrative frame of the process;

- Structure and human resources of the process;

- De-facto practices of the process;

- Document and information management systems of the process.

\section{v. VCA methodology}

\section{a. Method of collecting information}

Since the aim of the VCA Unit is to identify and assess points vulnerable to corruption, the team used multiple methods in its research. In order to conduct a VCA, it is important to make vulnerable points accessible to the researchers so that they can ultimately achieve an overview of the vulnerabilities in the process. The vulnerabilities identified open the door for bribery and embezzlement and also facilitates various other kinds of corruption defined in the third article of Afghanistan's Anti-Corruption Law.

Members of the VCA Unit used the methods below as tools for collecting data:

- General study of media reports; 
- Study and analysis of legal and administrative documents of the process;

- Interviews and open deliberation with the senior authorities of the process;

- Exclusive interviews with staff involved in the process;

- Holding group meetings and group interviews; and

- Other observations noted during field visits.

In order to identify the vulnerabilities to corruption more precisely and make its findings more credible, the VCA Unit defined specific questions that helped identify the ideas of visitors and officials engaged in the examination process. The team conducted interviews with officials, professors and students of universities based in the capital. This process started on December $18^{\text {th }}$ and ended on December $31^{\text {st }}$ 2012. The questionnaires used were divided into four sections, each probing for different type of information.

\section{b. Assessment and analysis of information obtained from different sources}

In light of the information collected from different sources and with reference to the standard criteria for identifying corruption opportunities, the VCA Unit identified several corruption vulnerabilities based on a cause and effect approach. It is worth mentioning that the findings of this research reflect the perspectives of the participants in the assessment and do not constitute evidence against any individual or entity.

\section{c. Method of identifying vulnerabilities to corruption}

Identifying vulnerabilities to corruption is based on the terms of article 3 of the Anti-Corruption Law, which includes the following in its definition of corruption:

- Bribery

- Embezzlement

- Stealing documents

- Illegal waste of official documents

- Violation of the limit of legal competency

- Abuse of power

- Obstacle in the way of implementing justice

- Misuse of government facilities, and official working hours in favor of personal matters

- Arbitrary leave of work without legal reason

- Hiding the truth

- Impersonating authorities

- Illegal accumulation of assets

- Forging Documents

- Receiving any kind of gift with the intention of proceeding or avoiding something

- Negligence on duty

- Disobedience of organization regulations 
- Discrimination based on tribal, religious, party, gender and personal differences within delegated tasks

- Proceeding or avoiding any other actions stipulated in the anti-corruption law

With due reference to the documents and evidence received during the assessment, and on the basis of the criteria for the identification of vulnerabilities to corruption, the identified vulnerabilities have been numbered, explained objectively and put in this report.

\section{d. Method of presenting recommendations}

The VCA Unit considered several sources of information in the process of developing recommendations to address the identified vulnerabilities, including comments made by interviewees as well as the researcher's own findings. The recommendations of this research are thus well founded and substantiated. Furthermore, the team considered the overall situation and possibilities of the ministries and other institutions, in order to ensure the applicability of the recommendations. The ministries and other entities can thus make use of the team's findings to mitigate vulnerabilities to corruption and improve their situations.

\section{Assessment of the Legal Framework and Legislative Documents Related to the Process}

The legal framework of a given process typically consists of all legal and administrative documents that pertain to the process and outline the rights and duties of the stakeholders involved. The legal framework typically includes articles of law, regulations, legislative decrees, decisions by the Council of Ministers, ministries' approved procedures, and other policies.

The existence of a robust legal frame will strengthen a particular area of work and allow it to function more effectively. It is also considered to be an effective method of preventing corruption. Sometimes the misinterpretation of an article or a term of the legal framework can cause confusion and favor corruption. Therefore legislators are responsible for providing strong definitions for an article or a term and ensuring that laws, regulations, decrees and procedures are consistent and clear.

However, even when legislators design exemplary legal frameworks, administrative changes, insufficient implementation capacity, and incorrect interpretations of legal documents can weaken the effectiveness of the legal framework and create unforeseen vulnerabilities. This phenomenon can also be observed in the internal examination process of universities and other higher education institutions. Accordingly, in addition to assessing other aspect of the process, the VCA Unit has taken the legal framework of the internal examination process into consideration in order to distinguish challenges and vulnerabilities to corruption.

\section{i. Interviewee's perspective of the legal framework}

With regard to the legal and administrative framework of the internal examination process, five questions were discussed with 24 people, including professors, graduates and high-ranking officials. Their responses helped to identify numerous aspects of the legal and administrative framework. The five questions were developed by considering the views of participants of round table focus group discussions, and incorporating the observations of researchers, as well as the study and analysis of legal and administrative documents. 


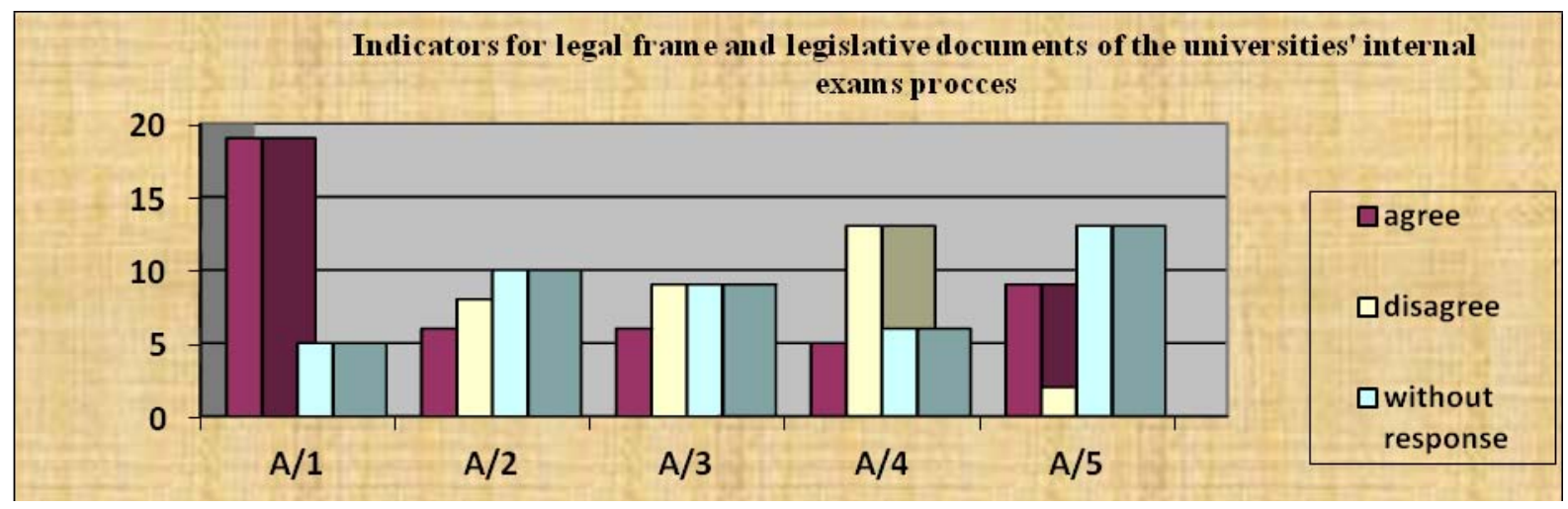

Chart 1: A brief overview of interviewees' responses

\section{ii. The existence of legislative documents}

This question has been put to 24 interviewees from whom 19 people were aware of the existence of procedure in this process, while five people expressed ignorance of the issue. The VCA Unit tried to gather and analyze all legal and administrative documents related to the universities' internal exams. The legal documents handed to the VCA Unit by officials of ministries and universities based in Kabul are listed below:

- Bill for the BA credit system of higher education institutes for BA;

- Bill for the exams of higher education institutes; and

- Decision of the joint meeting between MoHE leadership and student representatives of the capital based universities about the educational curriculum and the procedure of taking semester exams.

\section{iii. Sufficiency of the legal framework}

This question was posed to 24 people, from whom six interviewees believed that insufficiencies exist within the relevant legal documents. Nevertheless, eight people think that the documents and procedures are perfect, while the remaining 10 interviewees had no opinion about the matter. Given the facts received from different sources, however, some vague and vulnerable points have been identified in these two legal and administrative documents which require further elaboration.

One of the issues that potentially provide an avenue for corruption in the process of exams is the multitude of bills and procedures. As was previously mentioned, there are already three bills in force that pertain to the process, some of which are repetitive, vague, confusing and do not conform to accepted standards. The following sections briefly outline some of these issues in greater detail.

\section{iv. Bill for the BA credit system in higher education institutions}

The VCA's study and analysis of the bill indicates that it is mainly focused on how to organize and manage the credit system in the universities. Regarding exams, it stipulates a number of provisions which students should comply with before taking exams. In general, this bill is fairly robust. However, some of its articles are not applicable due to universities' inability to adopt the credit system. Although MoHE introduced this system long ago, capacity constraints have 
prevented its implementation it in all universities. Currently, the credit system is being adopted in some universities and faculties while in others the classic method is still more dominant. It is expected that MoHE will consolidate the system and put in place a single teaching method in all departments, faculties and universities.

\section{v. Exams bill for higher education institutions}

The exam bill for higher education institutes is more relevant for institutes in which the credit system has not been implemented yet and the classic method (block system) is carried out. This bill is the original foundation for conducting exams in higher education institutions. As pointed out before, certain articles of this bill are vague and will not produce appropriate results.

Article 12 of the exams' bill for higher education institutions states the conditions for participating in the final exams. The conditions to participate in the final exams include:

- Students who attended $75 \%$ of teaching hours can participate in the exams;

- If the student becomes injured because of unexpected incidents and cannot attend continuously and fails to meet the attendance requirement; and the situation becomes clear to the faculty, the absence of the student will be excused on the basis of the faculty's scholar's council approval;

- If a married female student cannot complete the required record of attendance due to being pregnant or giving birth, this kind of absence will be excused on the basis of the faculty's scholar's council approval; and

- Completion of the conditions which the educational institutes put in place according to their internal procedures.

Paragraph 1 conditions participation on completing 75\% of attendance, while paragraphs 2 and 3 of this article regulate unexpected circumstances which can arise from unforeseen incidents. Under the stipulated circumstances, students can take part in the exams even if they were unable to attain an attendance record of $75 \%$. This article could be seen as ambiguous and might therefore not be implemented as intended. The last paragraph of this article is also unclear and imposes other conditions on the educational institute which could be misused under certain circumstances.

\section{vi. Decisions of the meeting between the MOHE and student representatives}

This document was originally in the form of a joint resolution of MoHE and representatives of student affairs that was signed by the Ministry and disseminated as a circular to the universities for implementing. This procedure clarifies the two previous bills and explains how they are to be implemented in the universities.

Although MoHE issued this document as a unified procedure, the document cannot be seen as a procedure and should rather be viewed as a comprehensive resolution for tackling the challenges universities are faced with in terms of executing the two bills. As far as the VCA Unit is concerned, this document is useful for sorting out a number of challenges, but there remains the need for a sustainable and elaborated strategy for universities.

\section{vii. Personal decisions in the process}

Six interviewees out of 24 believe that the legal documents regulating the internal examination process of the universities paves the way for directors and other authorities to exercise undue 
personal discretion. Nine people opposed this notion because they felt that the legal documents are clear. The remaining interviewees had no opinion on the issue. Nevertheless, other sources indicate that the room for personal decisions by the directors engaged in the process is unjustifiably large due to the insufficiencies and inadequacies of the current legal documents.

\section{viii. Execution of the legal framework}

In response to this question the 24 interviewed people had a variety of opinions. Five interviewees believed the legal framework of the process was being implemented and abided by, while 13 complained of disobedience and non-execution. The other six did not have an opinion on the subject. Information collected from other sources indicates that the procedure is not observed or implemented correctly, mainly due to the vagueness of the procedure's articles. Normally, this procedure is in force in all universities based in Kabul, but in exceptional circumstances it does not come into force due to illegitimate influences.

As previously mentioned, the main problem of internal exams of the universities is that the bills are not enforced. The majority of interviewees responded negatively to the question "were the legislative documents of the process implemented properly?"

Most of the respondents felt that the multitude of different methods in the process of final exams used by teachers at the end of a semester is a sign that the legislative documents are not implemented. From the interviewees' point of view, had the legislative documents been implemented properly, all semester exams would be conducted using the same method. The following table offers an overview of the rules and regulations that the authorities and teachers have neglected to implement in the exams process:

\begin{tabular}{|c|c|c|}
\hline No & Rules and regulations not being implemented & $\begin{array}{l}\text { Title of the legal and } \\
\text { administrative document in } \\
\text { force }\end{array}$ \\
\hline 1 & $\begin{array}{l}\text { Exam committee duties: } \\
\text { 1. Monitoring implementation of educational curriculum } \\
\text { 2. Ensuring implementation of exam questions in accordance } \\
\text { with the teaching program } \\
\text { 3. Harmonizing each subject's questions with the } \\
\text { requirements of the procedures } \\
\text { 4. Assessing and solving complaints in respect to conducting } \\
\text { exams }\end{array}$ & $\begin{array}{l}\text { Semester exams procedure } \\
\text { Paragraph C, Article } 1 \text { of the } \\
\text { exams' committee's duties }\end{array}$ \\
\hline 2 & $\begin{array}{l}\text { The number of exam questions and the value in terms of } \\
\text { marks: } \\
\text { 1. The number of exam questions are between } 30 \text { to } 40 \text {, of } \\
\text { which } 20 \text { question are multiple-choice and have four } \\
\text { answers, while } 10 \text { to } 20 \text { questions require short analytic } \\
\text { and descriptive answers } \\
\text { 2. Marks for the answers are equally distributed with } 50 \% \\
\text { based on the multiple-choice questions and } 50 \% \text { on the } \\
\text { analytic and descriptive questions; }\end{array}$ & $\begin{array}{l}\text { Procedure for taking semester } \\
\qquad \text { exams } \\
\text { Article five: the number of exam } \\
\text { questions and their value }\end{array}$ \\
\hline
\end{tabular}




\begin{tabular}{|c|c|c|}
\hline 3 & $\begin{array}{l}\text { Time, provision of questions, schedule and the forms of } \\
\text { exams: } \\
\text { 1. Time for the exam: } 40 \text { to } 80 \text { minutes, depending on the } \\
\text { subject } \\
\text { 2. Exams are marked based on the model answers } \\
\text { provided by the related department. } \\
\text { 3. Results from the final exam of each subject are curved } \\
\text { and announced after a maximum three days. }\end{array}$ & $\begin{array}{l}\text { Procedure for taking semester } \\
\qquad \text { exams } \\
\text { Article six: time, provision of } \\
\text { questions, } \\
\text { exam schedule and form }\end{array}$ \\
\hline 4 & $\begin{array}{l}\text { Exam safety and transparency: } \\
\text { 1. There should be a special room for the exams' } \\
\text { committee in each faculty and institute } \\
\text { 2. All teachers of a department should be involved in } \\
\text { assessing the exam answers inside the committee's } \\
\text { room and have no right to take it out of there. }\end{array}$ & $\begin{array}{l}\text { Procedure for taking semester } \\
\text { exams } \\
\text { Article seven: exam safety and } \\
\text { transparency }\end{array}$ \\
\hline 5 & $\begin{array}{l}\text { Educational curriculum and method of teaching: } \\
\text { Lectures should be provided using power point presentations } \\
\text { ( } 5-7 \text { pages) for one hour and should avoid dictation. }\end{array}$ & $\begin{array}{l}\text { Procedure for taking semester } \\
\text { exams } \\
\text { Educational curriculum and } \\
\text { method of teaching }\end{array}$ \\
\hline 6 & $\begin{array}{l}\text { The way to take mid semester exams: } \\
\text { 1. Each subject has a mid-semester exam in the middle of } \\
\text { the semester } \\
\text { 2. If the students are absent during the mid-semester } \\
\text { exams, they will be granted the opportunity of a second } \\
\text { chance but will not be able to score higher than } 70 \% \text { on } \\
\text { the exam. }\end{array}$ & $\begin{array}{l}\text { Exams' bill for higher education } \\
\text { institutes } \\
\text { Article eight: The way to take mid } \\
\text { semester exams }\end{array}$ \\
\hline 7 & $\begin{array}{l}\text { Mark for each subject described as below: } \\
\text { Marks for the final exam of a subject should be between } 60 \% \\
\text { and } 70 \% \text { of the total marks of the subject. } 30 \% \text { to } 40 \% \text { of the } \\
\text { marks are allocated to the rest of the exams outlined in this bill. }\end{array}$ & $\begin{array}{l}\text { Exams' bill for higher education } \\
\text { institutes } \\
\text { Mark for each subject described } \\
\text { as below }\end{array}$ \\
\hline 8 & $\begin{array}{l}\text { Attempting to copy verbally or in writing, exchanging pages, } \\
\text { using books and other illegal notes as stipulated in the exam } \\
\text { rules will result in zero points in the subject. }\end{array}$ & $\begin{array}{l}\text { Exams' bill for higher education } \\
\text { institutes } \\
\text { Article twenty one: action against } \\
\text { copying, fraudulence and } \\
\text { disorder of exams rule }\end{array}$ \\
\hline 9 & $\begin{array}{l}\text { Article twenty-two: The way to review the results of final } \\
\text { exams: } \\
\text { 1. If the student seeks to challenge the result of his written } \\
\text { test, he should submit his request of dissatisfaction in } \\
\text { writing to the faculty office within three days. } \\
\text { 2. Revision will be conducted by the exam's committee } \\
\text { and in the presence of the subject's teacher and the } \\
\text { student. The committee's decision is final. }\end{array}$ & $\begin{array}{l}\text { Exams' bill for higher education } \\
\text { institutes } \\
\text { Article twenty two: The way to } \\
\text { review the result of final exams }\end{array}$ \\
\hline
\end{tabular}




\section{ix. Enforcement of the legal framework}

The issue has been discussed with 24 people, of whom 9 thought positively of it, 2 persons disagreed, and the rest had no opinion. Further research reveals that the obligation to enforce the legal framework exists, but there are also exceptional circumstances under which the regular implementation can be circumvented. Directors in charge of the process can demonstrate flexibility and make exceptions to the regulatory framework.

\section{x. Vulnerabilities related to the legal framework}

A quick assessment shows that there are three documents in force with regard to the internal exams of the universities: (1) educational curriculum and procedure for taking semester exams; (2) bill for the internal exams of higher education institutions and (3) bill for the credit system. These documents should be in force in all higher education institutions of the country. After analyzing the documents, conducting interviews, and collecting other relevant information, the following vulnerabilities were identified:

- The law for higher education has not been approved by parliament on the pretext of title selection such as Pohantoon and Danishgah, Pohanyar and Danishyar. No one is in a position to ask the parliament to give priority to the law for higher education and to approve it.

- The variety of the studying systems at the country's universities and the inability of MoHE to enforce a single system for studying. For instance, in one university the lessons are in a classic manner while in another the lessons follow the credit system.

- The multitude of legal documents regulating the process of exams. As previously mentioned, there are three legal documents and working procedures in place, which, on the one hand, provide avenues for corruption, and, on the other, create confusion among the higher education institutes charged with implementing the process.

- The insufficient implementation of bills and procedures in the exams process also obstruct the effective execution of the current legal documents.

- The existence of several documents causes ambiguities which allow officials and teachers to escape their responsibilities with regard to the implementation of bills and procedures.

- The bills and procedures of the Ministry are vague in some parts, making them less transparent, which might offer opportunities for corruption in the exam process.

- The lack of monitoring of the process by the designated authorities allows teachers to think that these documents need not be observed.

- The lack of consequences for ignoring rules and procedures gives teachers unlimited discretion, particularly to those who seek to benefit unfairly from the situation.

\section{xi. Recommendations}

In order to counter the negative consequences of administrative corruption and overcome the vulnerabilities within the legal framework of the exams process of universities, MoHE should, in cooperation with universities, implement these measures in the periods of time stipulated below:

a. The Parliament of the Islamic Republic of Afghanistan should give priority to the approval and finalization of the higher education law. 
- Responsible entity: Legislation commission and lower house of the parliament

- Deadline: three months after the issue of this report

b. MoHE should in consultation with the universities set up a unified studying regime for all higher education institutes and introduce the credit system, which is in place in the majority of the world's universities.

- Responsible entity: MoHE

- Deadline: one year after the issue of this report

c. MoHE, in order to prevent confusion among the universities, should in coordination with them consolidate the present legal documents pertaining to the exams process and seriously monitor the execution of the legal framework. In doing so, the ministry should wait until the endorsement of the higher education law and the universal introduction of the credit system.

- Responsible entity: MoHE department for coordinating academic affairs

- Deadline: four months after the issue of this report

d. In an attempt to maintain law and order, universities should take measures to identify those who violate the legal provisions and ensure they are appropriately punished as an administrative criterion.

- Responsible entity: universities and higher education institutions in coordination with the ministry

- Deadline: Continuously after the issue of this report

\section{Organizational Structure and Human Resources Related to the Internal Exams Process}

The organizational structure and human resources of an entity equipped with the necessary tools, talents, material and spiritual assets are crucial elements needed to achieve the aims and to execute the legal framework. The effectiveness of the organizational structure and human resources depends on the available infrastructure, commitment, skills, smartness, creativity, standards of the legal framework, political support, existing policies and strategies, proper working environment, appropriate terms of reference, and sound management.

Presence of professional cadres and smart teachers is necessary for the guidance of higher education institutions. Kabul based universities are in need of talented and experienced teachers in order to build a reputation and step up their quality. Therefore, one of the areas that has been assessed by the VCA Unit is the organizational structure and human resources of the examination process, in order to identify its deficiencies and vulnerabilities to corruption, as well as to present appropriate recommendations to improve the situation.

Primary results from the assessment indicate that certain elements of this area, such as organizational structure, terms of reference, human resources (teachers, administrative and civil service staff) and tools are partly available, but weaknesses in terms of implementing strategies and policies, working procedures and other plans diminish the effectiveness of teachers and 
officials' performances in the process of universities internal exams and MoHE. These weaknesses are elaborated below.

\section{i. Interviewee's perspective of the human resources structure}

In order to identify the vulnerabilities to corruption in this area, we raised seven questions with 24 people, including staff from different levels, teachers and graduates. Analysis of these answers and other evidence as well as observations made by the VCA Unit helped to identify the vulnerabilities to corruption of this process.

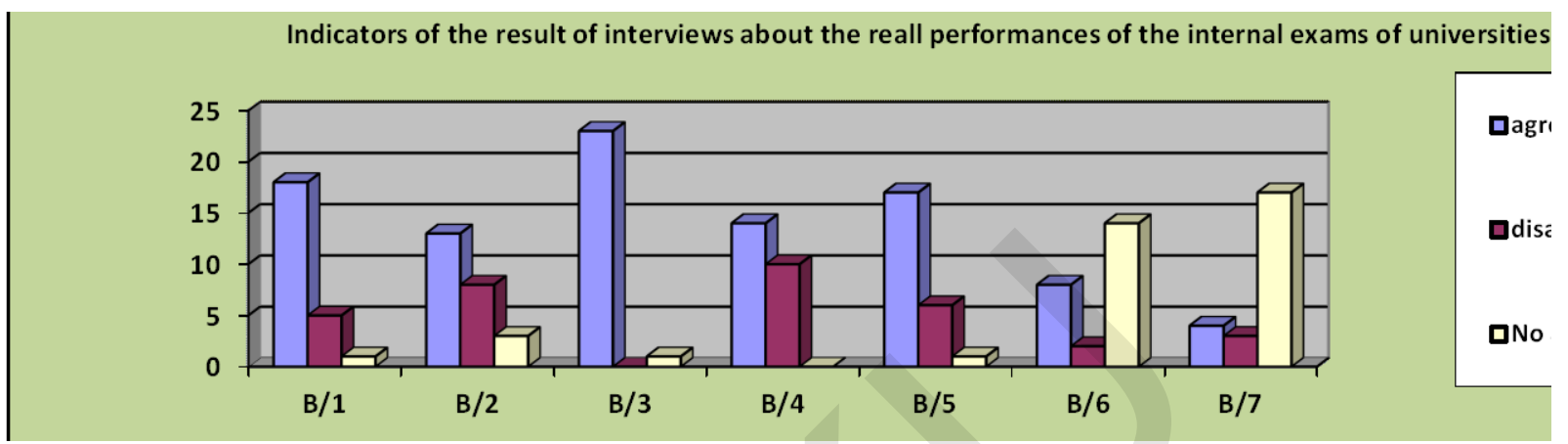

Chart 2: Response of the interviewees about the de facto practices of the process

\section{ii. Sufficiency of human resources}

In response to this question, 18 people out of 24 said that they believe that the human resources are sufficient; five people said they are insufficient. Only one person did not have an opinion about the issue. In general, based on information gathered from various sources, the organizational structure in universities using the credit system is not nearly detailed enough, particularly if one considers the size of work and number of students. As a result, the execution of the credit system at universities has several issues, including forcing students to register for subjects against their will, despite one of the merits of the credit system being that it allows the student to select subjects according to their personal tastes and capabilities.

\section{iii. Knowledge and experience of staff}

In response to the question of whether the experience and knowledge of staff are sufficient to perform their duties, 13 people out of 24 interviewees gave positive answers. The respondents expressed satisfaction about the staff's awareness of the examination process and felt that the knowledge and capacity of the teachers are satisfactory, particularly given the general level of education in the country, even though most of them do not have more than BA degrees. There are nevertheless a few teachers who have Masters or PhDs. Eight respondents however felt that most of the staff lack adequate knowledge and experiences and are not even capable of teaching in the classic manner. The low capacity of the teachers results in a loss of reputation for the scientific institutions of the country.

Some respondents furthermore complained about the teaching materials and methods of teachers. They indicated that teaching materials have not been changed in the past ten years. One interviewee said that the level of the teachers' literacy and their behavior are not acceptable. The teaching materials in use are based on the classic system and are so outdated that they do not come close to the standards of any other neighboring countries' universities. 
Unprofessionalism was another issue touched upon. Some interviewees believe that many teachers have been assigned to departments that do not correspond with their training. The remaining three people questioned withheld any comments.

It should be noted that the focus of this question and the subsequent discussions was on teaching staff, which is how most respondents framed their answer. Administrative staff has already been discussed in detail in the diploma distribution report.

\section{iv. Presence of terms of reference for staff}

In response to this question, only one person was unaware of the terms of reference for staff involved in the examination process; the other 23 knew of their existence. Most interviewees were aware that teachers have their terms of reference in which all their duties and competencies are stated. Other interviewees may not have been aware of the terms of reference per se, but were aware of the regulations in the higher education sector which stipulate all the responsibilities and duties of the teachers.

\section{v. Professionalism of staff}

Fourteen interviewees felt that staff have positive attitudes and considered their behavior towards visitors to be professional. However, 10 interviewees complained of the staff's unprofessional manners. As far as they are concerned, teachers do not live up to their academic ethics. They say that there are no significant differences between the behavior of a simple staff member and that of a teacher. The interviewees felt that teachers fail to provide students with the opportunity to ask questions and try to maintain silence in the classes. They also pointed out that some teachers conduct their classes in an autocratic manner and discriminate against students, in some cases even physically abusing them.

\section{vi. Staff engagement}

Of the 24 people asked about this topic, 17 respondents, most of whom are government officials, felt that the examination process is implemented as intended. Six respondents disagreed, while one did not have an opinion on the subject. Information from other sources shows that most teachers, despite being interested in the academic environment and teaching, are involved in various other activities. Teachers are subsequently frequently absent, which is why their lectures and notes tend to be repetitive and have not been renewed in numerous years.

\section{vii. Sincerity of staff}

In response to this question 8 interviewees felt that teachers and staff are sincere, with only two respondents thinking differently. Fourteen respondents did not have an opinion on the subject. Teachers might be said to lack loyalty because of restrictions to the teaching environment, their insufficient preparation for lessons, and their continuous use of their classic notes.

\section{viii. Abuse of final semester exams}

Only four interviewees believe that teachers and staff involved in the internal exams conduct themselves in an ethical manner and would not demand anything from the exam candidates. The remaining interviewees either did not have an opinion or felt unable to answer the question. 
Information and observations received from other sources indicate that the abuse of power might only occur occasionally.

\section{ix. Vulnerabilities related to human resources}

After analyzing the terms of references for some departments engaged in the examination process, assessing teachers' performances, recording interviewees' comments, and collecting information from other informative sources; the VCA Unit was able to identify a number of areas vulnerable to corruption. These are outlined below with the corresponding recommendations.

Limits of the organizational structure and the lack of teachers in universities (particularly in those that use the credit system) has obliged professors to teach extra hours as well as instruct courses not in their field of expertise.

- The recruitment policy has been changed to the effect of downgrading the value of candidates with a BA degree vis-à-vis those with a Masters degree. This could lead to a reduced recruitment of professional cadres at the universities. On top of that, hundreds of Afghans who received Masters and PhD degrees from abroad are coming back to the country and being employed by the government or private institutions.

- The limited professional capacity of university teachers and their unfamiliarity with the new teaching methods causes discontent amongst the students and resentment amongst teachers towards the students.

- One of the more serious issues uncovered in the ministry and universities is that administrative and academic positions are being mixed. For example, teachers who should just be teaching and researching are made to take on administrative task as well.

- This study shows that the way in which some authorities and directors behave towards visitors is not acceptable. The fact that they have teaching engagements while simultaneously being tied up in meetings contributes to the slowdown of daily routine and could pave the way for bribery.

\section{x. Recommendations}

Given the vulnerabilities in the organizational structure and human resource of the exams process of universities, the recommendations below should be heeded by the ministry, universities and higher education institutes in order to improve the situation:

a. A thorough assessment of universities' organizational needs for the implementation of the credit system is required, so that the Ministry is able to take effective measures to resolve the universities' current challenges.

- Responsible entity: MoHE in cooperation with universities

- Deadline : Three months after this report is issued

b. It is necessary to give priority to the recruitment of teachers with $\mathrm{PhD}$ and master degrees (as well as BA degree holders with high marks) through competitive process. MoHE should revise the hiring conditions of professional cadres in universities and higher education institutes.

- Responsible entity: MoHE

- Deadline: Three months after this report is issued 
c. MoHE should in cooperation with the universities and higher education institutes send teachers with BA degrees abroad so that they may gain master degrees. To enhance capacity building, teachers should be given specific academic tasks to help scale up their potential as well as improve the outcome of professional research.

- Responsible entity: MoHE in cooperation with universities

- Deadline: Continuously after this report is issued

d. MoHE should in cooperation with the universities lay out a plan for the separation of academic and administrative posts as soon as possible and put it in place. The ministry should furthermore be obliged to identify the directors being engaged in both administrative and teaching tasks and subsequently assign them to only of these positions.

- Responsible entity: MoHE

- Deadline: Three months after this report is issued

\section{De Facto Practices in the Internal Exams Process}

The purpose of mapping the universities' internal exams process in practice from the start to the end is to identify the challenges encountered, any ignorance of the legal framework, as well as any other aspects that could potentially contribute to the administrative corruption. By identifying these elements, it is hoped recommendations can be developed that will lead to an improvement of the situation. Before discussing the survey results, the steps of the examinations process which were observed are outlined.

\section{i. Stages in the internal exams process}

These stages include all the activities which were observed by or reported to the VCA Unit in the capital based universities. The majority of the information is based on interviews which were conducted separately with two teachers of Kabul based universities. The VCA Unit tried to acquire documents outlining the process, but failed on account of the information being confidential. For more detail on the information contained in the table please refer to the Annex.

\begin{tabular}{|c|c|c|c|c|c|}
\hline No. & Stage of the process & $\begin{array}{l}\text { No. of } \\
\text { steps }\end{array}$ & \multicolumn{2}{|c|}{$\begin{array}{c}\text { Grading of each } \\
\text { stage based on } \\
\text { its } \\
\text { vulnerabilities }\end{array}$} & Remarks \\
\hline 1 & Preparation at the university level & 6 & & & \multirow{6}{*}{$\begin{array}{l}\text { This grading is } \\
\text { made based on } \\
\text { the response of } \\
\text { the } \\
\text { interviewees. }\end{array}$} \\
\hline 2 & $\begin{array}{l}\text { Appointing examination committee at the } \\
\text { faculty level and scheduling exams }\end{array}$ & 7 & & & \\
\hline 3 & Administrative measures & 6 & & & \\
\hline 4 & Conducting exams & 6 & 1 & $1^{\text {st }}$ Grade & \\
\hline 5 & Announcing the results & 4 & & & \\
\hline 6 & Verification of students' complains & 6 & 2 & $2^{\text {nd }}$ Grade & \\
\hline 7 & Recording marks in the registry books & 3 & 3 & $3^{\text {rd }}$ Grade & \\
\hline \multicolumn{6}{|c|}{\begin{tabular}{|l|l} 
Types of Vulnerabilities & Bribery, illegal influence, fraud, etc.
\end{tabular}} \\
\hline
\end{tabular}


It should be pointed out that this process is based on the exams bill, bill for the credit system, and other relevant procedures which have been approved by the ministry for final semester exams, but in practice the regulatory framework is frequently not implemented. For instance, the twentieth step of the fourth stage is not being taken; teachers usually dictate some of the exam questions to the students.

\section{ii. Interviewee comments}

As well as documenting the process of universities' internal exams by gathering information through conducting exclusive interviews with teachers, the VCA Unit also consulted other informative options such as visiting mid-level authorities of the ministry and directorates, holding interviews with visitors, and making observations of relevant working processes of staff.

Results of interviews about the actual performence of universities' internal exams

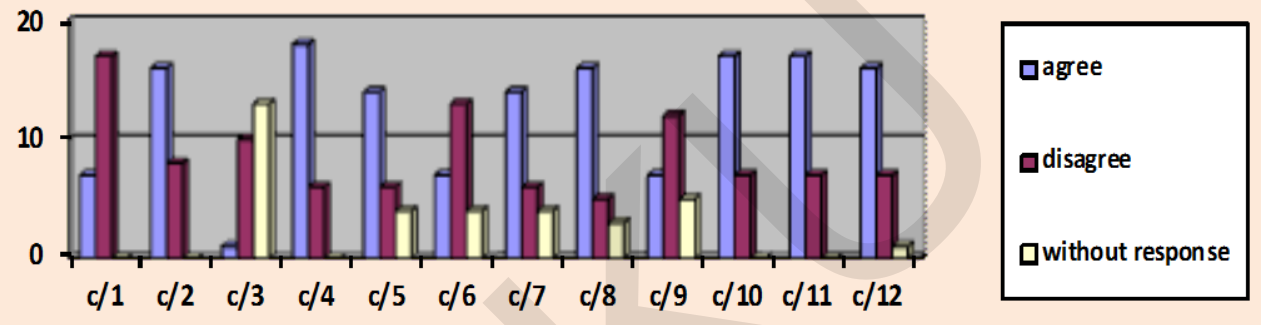

Chart 3: Demonstrates interviewees’ comments on questions c/1 to question c/12

\section{iii. Personal activities of staff}

Of the 24 people interviewed, seven believe that teachers and staff go after their own personal affairs during official working hours. Seventeen persons think otherwise and argued that the lack of staff and the accumulation of work would prevent them from being occupied with other things. Information received from other sources reveals, however, that some teachers, who have to be present at the universities during official working hours and carry out their duties, are in fact engaged in activities that have nothing to do with their work at the universities. This could have a negative impact on their academic research and scientific activities of the universities.

\section{iv. Management and control of staff performance}

Sixteen respondents believe that adequate internal controls at different levels of the process are available, while the rest feel otherwise. Other documents and evidence show that proper management of teachers is ensured by directors of departments, the relevant directorate of faculty, and directorate of the university. The management is even monitored by a team from MoHE. In terms of exams, it is the academic council of universities and faculties, the exams committee of the faculties that have the task of monitoring and evaluating the final exams of a semester. Consequently, we can say that management and control of the process is satisfactory. 


\section{v. Unofficial recognition of rights, duties and responsibilities}

Only one person spoke of the existence of unofficial distribution of rights, duties and responsibilities, compared to the 10 interviewees who insisted that duties are being delegated to the people in accordance with the terms of reference and that there are no financial incentives to cause such inequalities. The rest of the respondents had no opinion about the matter. Information from other sources however indicates that the unofficial distribution of duties and responsibilities is taking place in academic sectors, which causes the reform process to be impeded by some posts that are wrongfully occupied by certain teachers.

\section{vi. Undue influence and improper direction}

Eighteen respondents believe that unfair influence exists in the examinations process, while six interviewees think that there is no improper conduct. But information from other sources suggest extensive interference in the process, predominantly by high ranking government officials and Members of Parliament who put pressure on teachers to make failed students pass. One interviewee claimed that "the high authorities of the government and Members of Parliament pressure the Minister of Higher Education, who then does the same to the head of a given university, until the pressure exerted is finally extended through the faculty head and department director to a specific teacher".

In addition, some interviewees believe that the teachers themselves sometimes try to influence each other during the semester exams on behalf of students in order improve their grades. Nevertheless, some interviewees believe that in spite of these unfair interferences, teachers have not given in to such pressure. The majority of interviewees however claim that unfair influence and unlawful pressure, either from within the university or from outside, represents a serious vulnerability to corruption.

In response to this question 14 people felt that the examination process is being misled, while 6 disagree and four persons skipped answering this question. However, information received from other sources indicates that despite the irregularities outlined in $\mathrm{C} / 5$, there is only a slim possibility of misleading the process of universities' internal exams.

\section{vii. Gifts}

Seven respondents believe that gifts are sometimes exchanged during the examination process, but 13 people disagree with this idea while the others had no opinion about the subject. Information received from other sources indicates that unprofessional behavior of certain teachers does occur during the semester exams, such as threatening to fail students if they do not provide gifts. A number of interviewees also claimed that some students have access to the questions before the exams, which provides further proof of the extortion allegation. For instance, one interviewee said "I have not directly witnessed the act of taking gifts by the teachers, but as some students have access to the questions before the exams, it is a clear sign of such misconduct."

\section{viii. Awareness of corruption, misconduct and unprofessional behavior}

Fourteen interviewees believe that teachers have been made aware of what constitutes misconduct and unprofessional behavior. Another six argued that this is not the case, but that teachers should nevertheless have gained some awareness through the media and personal 
studies. The VCA Unit has found that the staff's technical understanding is much lower than the necessary level. Teachers should not just be experts in their subjects, but they should also have a minimal understanding of administrative corruption and its consequences.

\section{ix. Job security}

Sixteen interviewees think that teachers have sufficient job security, since it is guaranteed by the higher education law and other laws enforced in the country. The respondents also stated that the job security simultaneously implies that no one can change their position from one faculty to another without proper reasons. While three respondents did not have an opinion about this matter, five agreed that job security was provided by law, but not sufficiently enforced. Information from other sources indicates that by and large teachers and staff have sufficient job security, although this is in some cases breached.

\section{x. Conflicts of interest}

Of the 24 respondents, half did not think that there were any conflicts of interests for the teachers in the examination process, with which seven respondents disagreed. According to the information gathered from other sources, conflict of interest is not really a concern in the process. The likelihood that conflict of interests can occur is higher where financial gains are available, but certain interviewees claimed that in some classes the teacher's own son or daughter was present, and that the teacher subsequently tried to favor their children by offering better marks.

\section{xi. Non-compliance and variance of procedures}

Seventeen respondents claim that the majority of teachers are not executing the exams bill, procedures and other legislative documents in the examination process. The rest felt that teachers were implementing the regulations correctly. Although teachers have the obligation to give a mid-semester exam (which makes up $20 \%$ of the semester grade), many ignore the principle and make the final exam count for $100 \%$ of the grade. This example and many others indicate that teachers do not implement the legislative documents as intended, much to the students' annoyance. Teachers also design exams as they please; one teacher might use analytical questions, while the other uses technical ones. One teacher may provide questions with an empty space for answering, while the other uses multiple choice questions. In general, all these facts show that teachers overlook the significance of the issue and design exams without considering laws and regulations.

\section{xii. Satisfaction with the Complaint Investigation Committee}

The issue of students' satisfaction from the Complaint Investigation Committee's performance has been discussed with 24 teachers and students, of whom 17 persons believed in the impartial performance of the Committee; while seven interviewees questioned the Committee's impartiality due to its composition (only teachers are members of the Committee). According to students, the law grants them the right to complain about or challenge exam results, but it is not being implemented properly. In reality, if a student wants to have their exam papers checked, they may be threatened with failure by their teachers. Therefore most students do not dare to have their exam papers reassessed if they are unhappy with the marks received. 


\section{xiii. Provision of exam papers and answer-keys}

The procedures and exam's bill requires that all documents related to the preparation of exams, particularly the corresponding answer-keys, should be delivered to the relevant section. Sixteen respondents believe that this provision is being abided by, while seven persons think otherwise and argue that the majority of teachers have answer-keys for their subjects. Furthermore, in most cases teachers take the exam papers home with them home to mark and only pass them to the relevant academic management unit of the faculty after finishing.

\section{xiv. Vulnerabilities to corruption}

Administrative corruption in some universities in the form of giving extra marks to certain students and ignoring other students' rights is a matter of concern. The VCA Unit has investigated practices of this nature by researching informal activities, management and control of the examination process, informal distribution of rights and responsibilities, unfair interference, misguidance of directions, receiving gifts, awareness of teachers and universities' staff of corruption, unprofessional behavior, job security, and conflict of interest. As a result the following areas vulnerable to corruption have been identified and appropriate recommendations prepared:

- Senior government officials exercise undue authority in an attempt to influence academic processes, a deeply worrying situation for students, teachers and staff. If the situation is allowed to continue, the people of Afghanistan will witness more disorder and lower quality education in the country's universities. Such wrongful interference will ultimately damage the reputation of the universities and will bring into question the credibility of their graduates in the eyes of the Afghan people.

- Some information suggests that some of the teachers have not been professional in their conduct towards students, either during exams or the rest of the semester. As has been pointed out in the report, most of the interviewees have complained about the behavior of their teachers. They believe that the teachers' manners are incompatible with the academic environment. In some instances teachers were so aggressive and insulting towards the students that some cases ended in physical contact.

- This report also shows that some teachers misuse the exams as a tool to achieve their own agenda. Misusing exams for immoral issues or tribal, language, political and religious prejudices etc. are examples of how the examination process is vulnerable to the whim of teachers.

- Teachers frequently make use of methods for exams and giving marks which are not in accordance with the relevant procedures and bills.

- The Students' Complaints Committee has not necessarily been impartial and somehow or other favors teachers. It gives rise to the disappointment of students and impedes justice.

- A certain number of teachers are also engaged in private activities when on duty, while other teachers are occupied with management tasks. This results in a lack of available teachers for university lectures and limits the time available to prepare the subject being taught.

\section{xv. Recommendations}

a. MoHE should design and put in place comprehensive strategies by which the unfair interferences of higher authorities of the ministry, Members of Parliament, 
judicial power and government can be stopped. Furthermore, MEC may call upon Parliament to put an end to their interferences into the government's affairs.

- Responsible entity: MoHE and MEC

- Deadline: three months after the report is issued

b. MoHE should, in order to prevent discrimination and harassment in academic institutions, assess universities seriously. If allegations are substantiated, the suspects should be handed over to the proper authorities. Meanwhile, the ministry should strengthen and maintain its monitoring policy to consider such cases.

- Responsible entity: MoHE

- Deadline: continually after this report has been issued

c. MoHE should, in order to strengthen and develop the quality of teaching, address all universities, governmental and non-governmental higher education institutes via a circular and order the enforcement of academic accountability of teachers in a fixed time frame. In addition, the Ministry should, in cooperation with the leadership of universities and other higher education institutes, monitor the execution process of the order.

- Responsible entity: MoHE

- Deadline: continually after this report is issued

d. Designing a comprehensive monitoring mechanism is one of the important tasks of universities in accordance with the rules and regulations. Actively monitoring the process of implementing legal documents by the using different informative sources (such as students and teachers' associations) can bridge the gaps identified in various areas. Hence, universities and higher education institutes should in coordination with MoHE design such a mechanism in a fixed time and incorporate the comments of students and teachers' association.

- Responsible entity: Universities in coordination with MoHE

- Deadline: continually after this report is issued

e. The universities should set up complaints committees comprised of trustworthy people to pave the way for justice. Furthermore, universities should attach complaint boxes to different areas of universities so that the students make their voices heard.

- Responsible entity: Universities and higher education institutes.

- Deadline: continually after this report is issued

\section{Information Management in the Internal Exam Process}

This is the fourth aspect of the universities' internal examination process included in this assessment. The way in which documents and information are organized has a significant implication for the organization's performance. Undoubtedly, if the archives, documents and other evidence of an organization are left unorganized, negative impacts will be noticed in its service offering. On the contrary, an efficient information management system will improve service and staff responsiveness, as well as speed up work in the process. 
The purpose of assessing this area is to identify challenges which can end up being vulnerabilities to corruption. In order to understand the information management system in place, the questions discussed below were used.

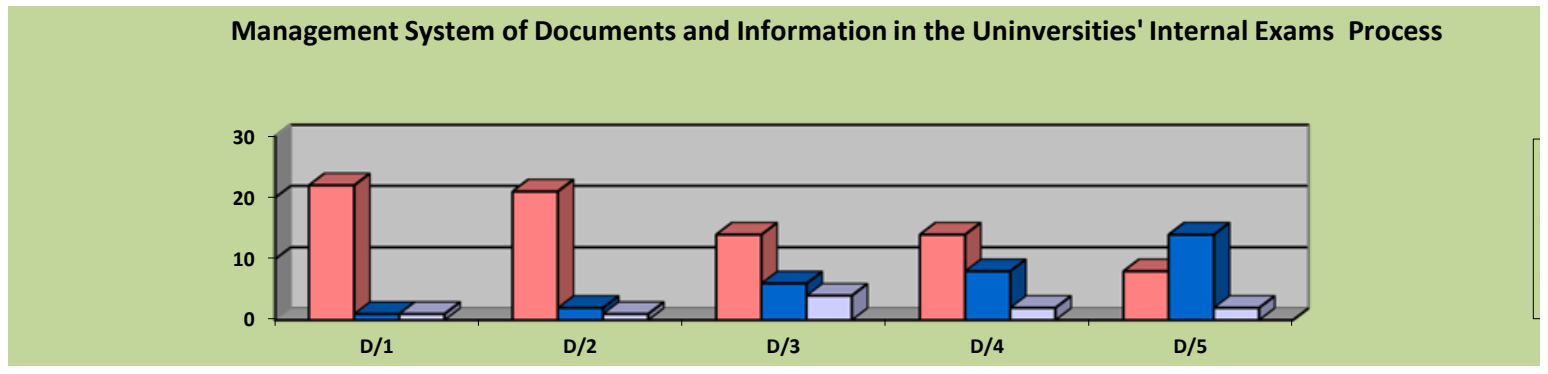

Chart 4: Interviewees' comments on question $d / 1$ to $d / 5$

\section{i. Current practices}

Of the 24 people interviewed, 22 respondents described the current situation as disorganized and in need of improvement. Only one person thought well of the current system, believing that filing documents as hard copies or hand notes is safer than using an electronic system and can prevent fraud. However, information from other sources demonstrates that despite the efforts made by MoHE, most teachers so far have not used a computer and correspondence is mainly done by hand notes and classic methods. Even grades are still recorded using the system in place during the King Zaher era.

\section{ii. The existence of a system for information management}

A majority of 21 respondents believe that the current mechanism is clear and simple, and only two interviewees find the current situation worrying. They argue that the current document management system is based on circumstances that no longer persist, and that the number of documents that have been accumulated over time are an obstacle to the timely accessing of information and documents. The VCA Unit has information that indicates in some cases even a hard copy record keeping system is lacking, and information is provided verbally.

\section{iii. Time intensiveness of the system}

Fourteen interviewees feel that gaining access to the documents in the internal exams section of universities is time consuming. Six people however disagree and say that there is a clear method through which the staff can facilitate the process and provide the visitors with the required documents. Nevertheless, information received from other sources indicates a time consuming and chaotic process for gaining access to the documents.

\section{iv. Information security}

A majority of 14 interviewees believe that documents are safe in the departments, but eight were of a different opinion. Information received from individual meetings shows that high level directors are also concerned about the current situation of the system. Despite serious measures and facilities to protect documents such as students' records, the system still appears vulnerable to them. 


\section{v. Potential for misuse of the information management system}

Although 8 interviewees felt that it is possible to manipulate the documents of diploma applicants, a majority of 14 persons said it was impossible to manipulate documents on account of information being accumulated in different sections and departments. However, information received from other sources provided many examples in which the filing system of semester exams was misused. Specifically, students who failed their exams on several occasions had their grades altered. In other cases students who had not earned enough marks to qualify for the cadre still ended up making the grade.

Interviewees even spoke of cases in which people who had failed a subject several times are now working as teachers in universities. One interviewee said that the "filing system in the faculty academic management unit is not safe. If the director or other staff are not honest, they can easily and regardless of the teachers' views change a student's records and marks to make the failed student a cadre or top up someone's marks".

\section{vi. Vulnerabilities to corruption}

In order to avoid the repetition of issues already discussed in previous sections, this section only focuses on two different areas identified during this assessment:

- According to department directors, one of the major deficiencies of the current document and information management system is teachers' frustration with the need to use computer technology. To improve the situation, they have been trained to provide soft copy of exam grades to the teaching section or to the related departments. The relevant department is then able to easily put all the information into its database or excel sheet.

- The falsification of documents and information related to the exams process is possible in the Faculty academic management unit and thus represents a vulnerability to corruption.

\section{vii. Recommendations}

a. Teachers should be able to organize their work by the use of their own computers. What the universities' authorities can do is to provide computer training for the teachers and make it mandatory for them to computerize the relevant information so that they can play their role in improving the filing and information management system and other academic areas.

- Responsible entity: MoHE

- Deadline: continually after this report is issued

b. In an attempt to prevent the falsification of documents, authorities of universities should deny individual access to documents and information and make sure that qualified and accountable people are recruited for the archiving of students' documents and grades in the exams section. In addition, some useful article should be added to the regulations and procedures of the examinations process which could limit attempts to alter documents.

- Responsible entity: MoHE

- Deadline: three months after this report is issued 


\section{Sources}

- Bill for the credit system of higher education institutes for BA period in Afghanistan

- $\quad$ Bill for the higher education institutes exams

- Decision of the joint meeting between MoHE leadership and student representatives of the capital based universities about the procedure of taking semesters' exams and educational curriculum.

- $\quad$ Focus group meeting minutes conducted in Kabul University on 17 Jaddi 1391

- Meetings and discussions with the senior officials of the Ministry and Universities.

- Meetings with the chancellors of Bamian and Badakhshan Universities

- Interviews with 24 subjects including professors, students and university officials.

- The team members' direct observations.

- Ministry and Universities' websites:

www.mohe.gov.af

www.ku.edu.af

www.kmu.edu.af

www.kpu.edu.af

www.keu.edu.af

www.kardan.edu.af 


\section{Annex}

\begin{tabular}{|c|c|c|}
\hline \multicolumn{3}{|c|}{ Working Procedure for the Internal Exams of the Government's Universities } \\
\hline Base & $\begin{array}{l}\text { This process is based on the verbal descriptions of teachers } \\
\text { and directors of different levels engaged in the process, and } \\
\text { observations of a few classes during final semester exams in } \\
\text { the capital based universities }\end{array}$ & \\
\hline Aim & $\begin{array}{l}\text { Identifying vulnerable areas to corruption in the internal } \\
\text { exams of universities and presenting recommendations for } \\
\text { improving the process }\end{array}$ & \\
\hline No & Stages and Steps & $\begin{array}{l}\text { Responsible authority for } \\
\text { implementing the process }\end{array}$ \\
\hline \multicolumn{3}{|c|}{ First Stage: Preparation at the university level } \\
\hline 1 & Holding meeting of universities' academic council & Universities' leadership \\
\hline 2 & Determining date for the beginning of exams & Universities' academic council \\
\hline 3 & $\begin{array}{l}\text { Submitting proposal to the Ministry of Higher Education for } \\
\text { approval }\end{array}$ & Universities' leadership \\
\hline 4 & Agreement and approval of the ministry & The Ministry of Higher Education \\
\hline 5 & Appointing central committee at the university level & Academic council \\
\hline 6 & $\begin{array}{l}\text { Declaration of the academic council's agreement } \\
\text { communicated to the faculties and related departments }\end{array}$ & $\begin{array}{l}\text { Directorate of the university's } \\
\text { office }\end{array}$ \\
\hline \multicolumn{3}{|c|}{ Second Stage: Appointing exam committees at the faculty level and preparing exam schedules } \\
\hline 7 & Holding meeting of the academic council of faculties & Faculty \\
\hline 8 & Appointing exams' committee at the faculty level & Academic council \\
\hline 9 & Preparing exam schedules at the faculty level & Exams' committee \\
\hline 10 & $\begin{array}{l}\text { Presenting exams' schedules to the meeting of exams' } \\
\text { central committee for consolidation }\end{array}$ & Faculty \\
\hline 11 & $\begin{array}{l}\text { Consolidation and comparison of faculty schedules at the } \\
\text { university level }\end{array}$ & $\begin{array}{l}\text { Coordination meeting of faculties } \\
\text { chaired by the deputy of } \\
\text { students' affairs }\end{array}$ \\
\hline 12 & Approval of exam schedules at the level of each faculty & Coordination meeting of faculties \\
\hline 13 & $\begin{array}{l}\text { Declaration of schedules via advertisement board and other } \\
\text { faculty communication to the teachers and students }\end{array}$ & $\begin{array}{l}\text { Faculty academic management } \\
\text { unit of faculties }\end{array}$ \\
\hline \multicolumn{3}{|c|}{ Third Stage: Administrative measures } \\
\hline 14 & Collection of attendance sheets of classes by lab technician & $\begin{array}{l}\text { Faculty academic management } \\
\text { unit }\end{array}$ \\
\hline 15 & Analysis of attendance sheet & $\begin{array}{l}\text { Faculty academic management } \\
\text { unit }\end{array}$ \\
\hline 16 & Preparing list of students not eligible for exams & $\begin{array}{l}\text { Faculty academic management } \\
\text { unit }\end{array}$ \\
\hline 17 & $\begin{array}{l}\text { Declaration of decision to exclude students by the lab } \\
\text { technician }\end{array}$ & Lab technician \\
\hline 18 & $\begin{array}{l}\text { Preparation of exam results sheet forms and recording the } \\
\text { students attendance for the purpose whether student is } \\
\text { completed the minimum required attendance in the or not }\end{array}$ & $\begin{array}{l}\text { Faculty academic management } \\
\text { unit }\end{array}$ \\
\hline 19 & $\begin{array}{l}\text { Submitting list of exam marks to the teachers according to } \\
\text { the subject by the lab technician }\end{array}$ & $\begin{array}{l}\text { Faculty academic management } \\
\text { unit via lab technician }\end{array}$ \\
\hline \multicolumn{3}{|c|}{ Fourth Stage: Conducting exams and announcing the results } \\
\hline 20 & $\begin{array}{l}\text { Provision of exam questions with the answer-key to the } \\
\text { department in order to select appropriate questions for the } \\
\text { subject's exam. }\end{array}$ & Teacher of the subject \\
\hline 21 & Approval of the selected questions. & Directorate of department \\
\hline
\end{tabular}




\begin{tabular}{|c|c|c|}
\hline 22 & Submission of questions to the subject's teacher & Directorate of department \\
\hline 23 & Presence in the class and taking students' attendance record & Teacher of the subject \\
\hline 24 & $\begin{array}{l}\text { Delivery of the exam questions with the blank pages } \\
\text { stamped by the directorate of department }\end{array}$ & Teacher of the subject \\
\hline 25 & $\begin{array}{l}\text { Answering the exam questions and presenting it to the } \\
\text { teacher of the subject within fixed time }\end{array}$ & Student \\
\hline \multicolumn{3}{|c|}{ Fifth Stage: Scoring and announcement of the exams results } \\
\hline 26 & Student answers assessed & Teacher of the subject \\
\hline 27 & Recording it to the list of marks for the subject & Teacher of the subject? \\
\hline 28 & Submission of the papers to the department & Teacher of the subject \\
\hline 29 & Announcement of the results & $\begin{array}{l}\text { Faculty academic management } \\
\text { unit }\end{array}$ \\
\hline \multicolumn{3}{|c|}{ Sixth Stage: Verification of students' complaints } \\
\hline 30 & Providing letter of complaint to the directorate of university & Student \\
\hline 31 & Reference of the university's directorate to the faculty & Directorate of university \\
\hline 32 & Reference of faculty to the exams committee & Faculty's directorate \\
\hline 33 & $\begin{array}{l}\text { Assessment of the student's complaint and setting up the } \\
\text { complaints investigation committee }\end{array}$ & Faculty's exams committee \\
\hline 34 & $\begin{array}{l}\text { Holding meeting to verify students complaints in the } \\
\text { presence of teacher and two members of complaints } \\
\text { investigation committee }\end{array}$ & $\begin{array}{l}\text { Complaints } \\
\text { committee }\end{array}$ \\
\hline 35 & Mutually satisfying agreement (student and teacher) & $\begin{array}{l}\text { Complaints } \\
\text { committee }\end{array}$ \\
\hline \multicolumn{3}{|c|}{ Seventh Stage: Recording marks in the registry book } \\
\hline 36 & $\begin{array}{l}\text { Filing the first of three copies of the marks in the related } \\
\text { department, delivering the second copy to the Faculty } \\
\text { academic management unit, and attaching the last copy to } \\
\text { the advertisement board }\end{array}$ & Directorate of department \\
\hline 37 & $\begin{array}{l}\text { Recording the result of exams in the registry book according } \\
\text { to the marks list and saving the subject's list of marks }\end{array}$ & $\begin{array}{l}\text { Faculty academic management } \\
\text { unit }\end{array}$ \\
\hline 38 & Delivery of a copy of the results to the students' department & $\begin{array}{l}\text { Faculty academic management } \\
\text { unit }\end{array}$ \\
\hline
\end{tabular}

